\title{
GAMBARAN SAFETY CLIMATE DAN INTERVENSI PROGRAM KESELAMATAN DI PROYEK Z PT.X
}

\author{
Agra Mohamad Khaliwa ${ }^{1}$, Febby Fauzia $^{2}$, Annisa Elfariyani ${ }^{3}$, M Rahmanda \\ Lintang Putranto ${ }^{4}$, Zulkifli Djunaidi ${ }^{5}$ \\ Departemen Keselamatan dan Kesehatan Kerja ${ }^{1}$, Departemen Keselamatan dan Kesehatan \\ Kerja $^{2}$, Fakultas Kesehatan Masyaratakat, Universitas Indonesia \\ agra.mohamad01@ui.ac.id ${ }^{1}$, zul@ui.ac.id²
}

\begin{abstract}
Safety Climate in contruction sectors has been used to assess employees perception of safety knowledge and it's implementation on the field. Safety climate implementation could positively influence workers knowledge, motivation, attitudes, and behavior regarding safety as well as to reduce incident consequences. This study was conducted to describe safety climate in Project $Z$, a construction site owned by PT. X. This research uses a quantitative approach with stratified random sampling method using closed questionnaire distributed to total of 80 construction workers. The variables involved in the assessment varies from commitment, safety as value, accountability, leadership, empowerment, communication, training all levels, and owner involvement. These variables act as determinants for safety climate on a scale of 1-5 based on S-CAT Assessment Tools. The results of this study shows that project $Z$ has an average score of 3.79 which is fall under proactive category. However, variables such as training, and owner involvement are still below average.
\end{abstract}

Keywords $\quad$ : Safety climate, Construction, Safety Climate program

\begin{abstract}
ABSTRAK
Safety Climate dalam sektor konstruksi memiliki peran untuk melihat persepsi karyawan mengenai penerapan dan pemahaman kondisi lapangan terkait keselamatan. Penerapan safety climate yang baik dapat secara positif mempengaruhi pengetahuan, motivasi, sikap, dan perilaku keselamatan karyawan, serta mengurangi konsekuensi insiden. Penelitian ini dilakukan untuk mendeskripsikan iklim keselamatan pada Proyek Z, sebuah lokasi konstruksi milik PT. X. Penelitian ini menggunakan pendekatan kuantitatif dengan metode stratified random sampling menggunakan kuesioner tertutup yang dibagikan kepada total 80 pekerja konstruksi. Variabel yang terlibat dalam penelitian ini beragam dimulai dari commitment, safety as value, accountability, leadership, empowerment, communication, training all levels, hingga owner involvement. Variabel variable ini digunakan sebagai penentu iklim keselamatan dengan skala 1-5 berdasarkan kuesioner penilaian S-CAT . Hasil dari penelitian menunjukan bahwa proyek $\mathrm{Z}$ memiliki rerata skor 3,79 yang masuk kedalam kategori proaktif. Namun, terdapat variabel pelatihan dan keterlibatan pemilik masih di bawah rata-rata.
\end{abstract}

Kata Kunci : Iklim Keselamatan, Konstruksi, Program Iklim Keselamatan

\section{PENDAHULUAN}

Berdasarkan data Badan Pusat Statistik (BPS) Indonesia, diketahui bahwa pekerja yang terlibat di sektor konstruksi terus meningkat. Tenaga kerja yang tercatat di sektor konstruksi berjumlah 5 juta orang yang mewakili 5,3\% dari seluruh tenaga kerja industri. Tingkat pendidikan pekerja pada pekerja konstruksi relatif rendah, lebih dari $50 \%$ pekerja adalah lulusan Sekolah Dasar, bahkan 1,5\% dari seluruh pekerja konstruksi tidak mengenyam pendidikan formal (Soemardi et al, 2009). Pelaksanaan Keselamatan dan Kesehatan Kerja (K3) dalam konstruksi cukup rumit, hal ini disebabkan karena sektor konstruksi yang memiliki dinamika kerja yang cepat berubah untuk mengejar target pekerjaan. Selain itu, satu proyek konstruksi memang melibatkan banyak subkontraktor yang terkadang menghambat proses komunikasi antar organisasi. Untuk mengatasi kendala penerapan $\mathrm{K} 3$ di bidang konstruksi, maka diperlukan program K3 sebagai salah satu cara untuk meningkatkan kesadaran akan 
keselamatan dan kesehatan kerja. Untuk mengetahui persepsi pekerja tentang penerapan K3, diperlukan pengukuran Safety Climate untuk mengukur perspektif pekerja terhadap organisasi dalam melaksanakan program K3. Salah satu faktor yang mempengaruhi Safety Climate adalah komitmen manajemen, komunikasi, dan keterlibatan pekerja dalam upaya penerapan K3 (Cigularov et al, 2010).

Safety Climate dalam organisasi didefinisikan sebagai persepsi bersama di antara karyawan mengenai apa yang dihargai, diharapkan, dihargai, dan diperkuat di tempat kerja sehubungan dengan keselamatan (Zou, 2010). Hal ini dapat secara positif mempengaruhi pengetahuan, motivasi, sikap, dan perilaku keselamatan karyawan, serta mengurangi hasil cedera (Probst, 2019; Zohar, 2014). Probst mengembangkan penelitian tentang iklim keselamatan berdasarkan konstruksi menunjukkan bahwa Safety Climate Assessment Tool (S-CAT) adalah alat yang andal dan valid bagi perusahaan konstruksi untuk menilai sendiri iklim keselamatan mereka. Telah terjadi pergeseran dari ketergantungan pada indikator retrospektif yang tertinggal, seperti tingkat insiden yang dapat dicatat, menuju fokus pada indikator utama yang pengukurannya dapat memungkinkan perusahaan untuk secara proaktif memantau dan terus meningkatkan lingkungan keselamatan mereka. Salah satu indikator utama yang telah terbukti andal dan konsisten memprediksi berbagai hasil terkait keselamatan adalah iklim keselamatan organisasi.

Penelitian ini bertujuan untuk melakukan pengukuran Safety Climate di PT. X, salah satu perusahaan konstruksi terbesar di Indonesia. Secara khusus akan mengukur Proyek $\mathrm{Z}$ yang telah mengimplementasikan program K3. Skor Safety Climate yang terkumpul akan menjadi dasar untuk merekomendasikan program peningkatan program K3 di Proyek Z.

\section{METODE}

Penelitian ini menggunakan pendekatan kuantitatif dengan kuesioner tertutup NIOSH Safety Climate Assessment TOOLS (S-CAT) untuk menggambarkan faktor-faktor kritis safety climate ke dalam 8 variabel yaitu: Mendemonstrasikan komitmen manajemen (Commitment), Menyelaraskan dan mengintegrasikan keselamatan sebagai nilai (Safety as Value), Memastikan akuntabilitas di semua tingkatan (Accountability), Meningkatkan kepemimpinan keamanan lokasi (Leadership), Memberdayakan dan melibatkan pekerja (Empowerment), Meningkatkan komunikasi (Communication), Pelatihan di semua tingkatan (Training All Levels), Mendorong keterlibatan pemilik/klien (Owner Involvement). Secara khusus, variabel ini mencerminkan tingkat kematangan safety climate mulai dari "inattentive, reactive, compliant, proactive hingga exemplary" untuk masing-masing dari delapan faktor. Kami mendapatkan total 57 pekerja dan staf menggunakan stratified random sampling untuk mengklasifikasikan pekerja sebanyak $75 \%$ dan staf sebanyak $25 \%$ dari total populasi.

Data yang dianalisis disajikan dalam bentuk diagram batang dari hasil kalkulasi menggunakan aplikasi SPSS Versi 25. Hasil analisis akan menggunakan skala 1-5 dengan kriteria 1: inattentive, 2 : reactive, 3 : compliant, 4: proactive, dan 5: exemplary. Hasil angka diperoleh dari rerata data yang diambil melalui kuesioner penelitian dan dianalisis menggunakan in-depth analysis dengan dokumen pendukung seperti literatur dan telaah dokumen program keselamatan perusahaan.

\section{HASIL}

Akumulasi data dari populasi umum pekerja di Proyek Z menyiratkan bahwa iklim keselamatan secara keseluruhan secara umum masuk ke dalam kategori proactive dengan skor 3,79. Dari delapan 
variabel yang diamati, persentase tertinggi berasal dari indikator 'Commitment' dan persentase terendah berasal dari indikator Training all Levels'. Namun, ada 3 variabel yang nilainya di bawah rata-rata umum, yaitu: Communication (3,75), Training All Levels $(3,3)$ dan Owner Involvement $(3,61)$.

\section{Total Nilai Safety Climate Proyek}

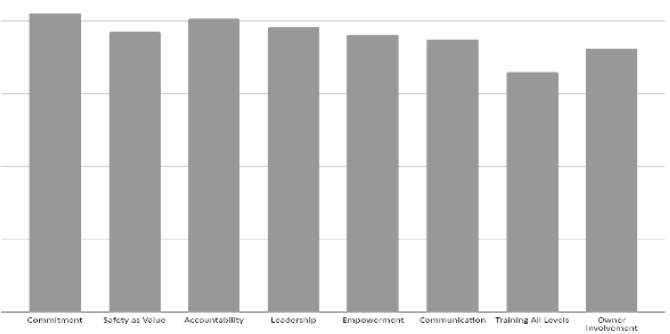

Gambar 1. Total Nilai Safety Climate Proyek

Nilai Variabel Commitment Pekerja dan Staf

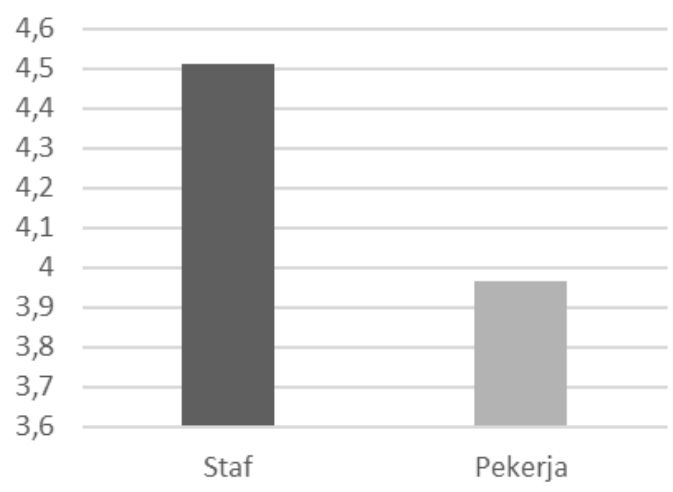

Gambar 2. Nilai Commitment Pekerja dan Staf

Hasil pengambilan kuesioner terkait commitment dapat dilihat pada gambar 2 yang menunjukan bahwa nilai commitment pekerja ada pada angka 3,96 dan staf memiliki nilai 4,51 dari skala 5

Nilai Variabel Safety as Value Pekerja dan Staf

Hasil pengambilan kuesioner terkait safety as value dapat dilihat pada gambar 3 yang menunjukan bahwa nilai safety as value pekerja ada pada angka 3,78 dan staf memiliki nilai 4,01 dari skala 5

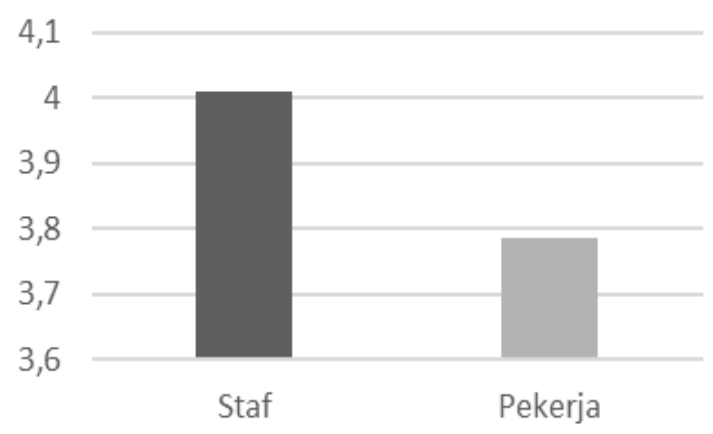

Gambar 3. Nilai Safety as Value Pekerja dan Staf

Nilai Variabel Accountability Pekerja dan Staf

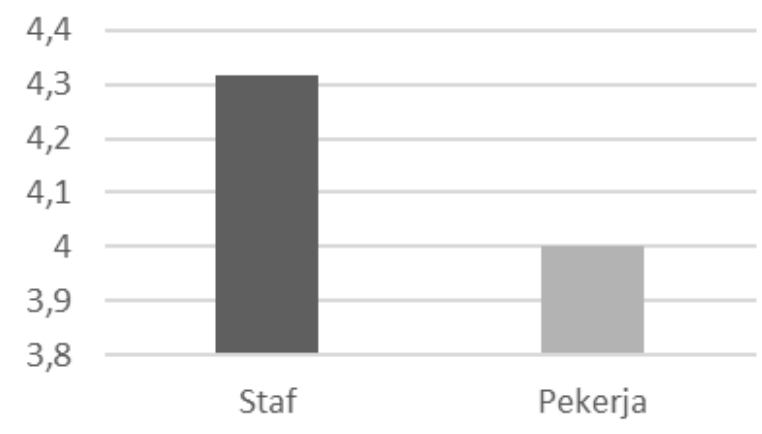

Gambar 4. Nilai Safety as Value Pekerja dan Staf

Hasil pengambilan kuesioner terkait accountability dapat dilihat pada gambar 4 yang menunjukan bahwa nilai accountability pekerja ada pada angka 4 dan staf memiliki nilai 4,32 dari skala 5

\section{Nilai Variabel Leadership Pekerja dan} Staf

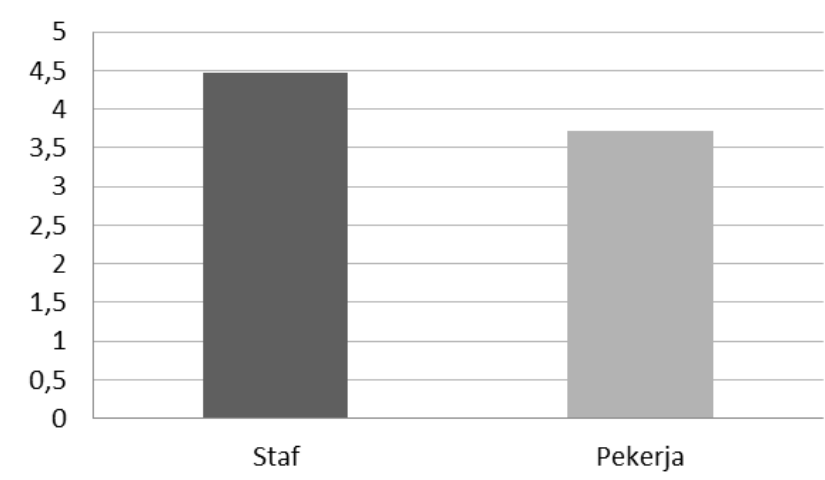

Gambar 5. Nilai Leadership Pekerja dan Staf 
Hasil pengambilan kuesioner terkait leadership dapat dilihat pada gambar 5 yang menunjukan bahwa nilai leadership pekerja ada pada angka 3,71 dan staf memiliki nilai 4,47 dari skala 5

\section{Nilai Variabel Empowerment Pekerja dan Staf}

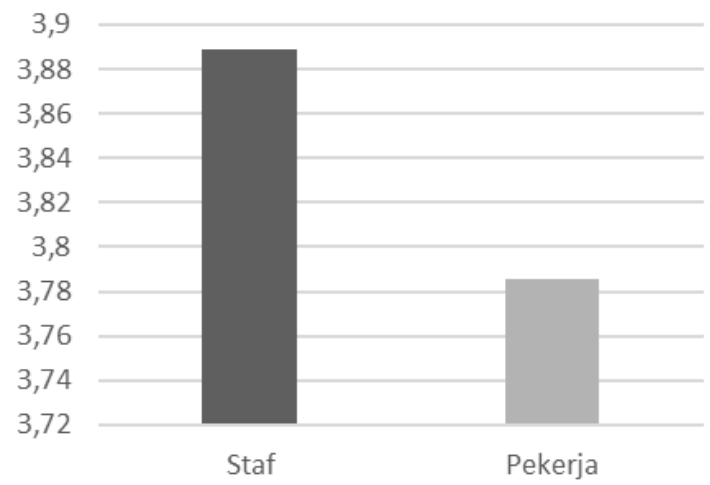

Gambar 6. Nilai Empowerment Pekerja dan Staf

Hasil pengambilan kuesioner terkait empowerment dapat dilihat pada gambar 6 yang menunjukan bahwa nilai empowerment pekerja ada pada angka 3,78 dan staf memiliki nilai 3,88 dari skala 5

\section{Nilai Variabel Communication Pekerja dan Staf}

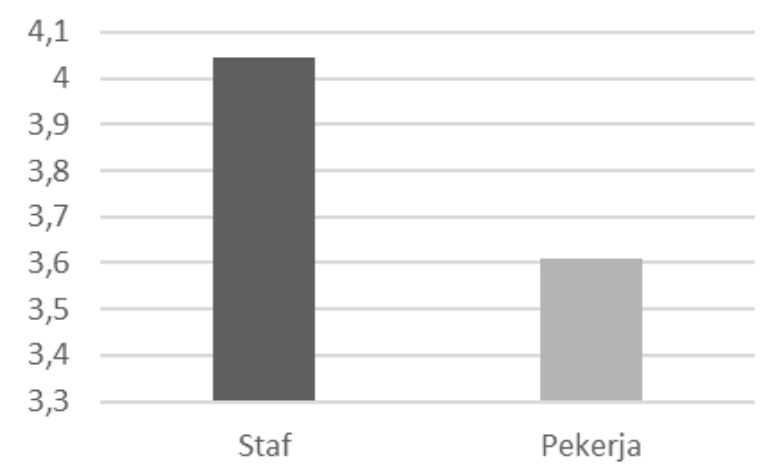

Gambar 7. Nilai Communication Pekerja dan Staf

Hasil pengambilan kuesioner terkait communication dapat dilihat pada gambar 7 yang menunjukan bahwa nilai communicationt pekerja ada pada angka 3,61 dan staf memiliki nilai 4,04 dari skala 5

\section{Nilai Variabel Training All Levels Pekerja dan Staf}

Hasil pengambilan kuesioner terkait training all levels dapat dilihat pada gambar 8 yang menunjukan bahwa nilai training all levels pekerja ada pada angka 3,34 dan staf memiliki nilai 3,18 dari skala 5

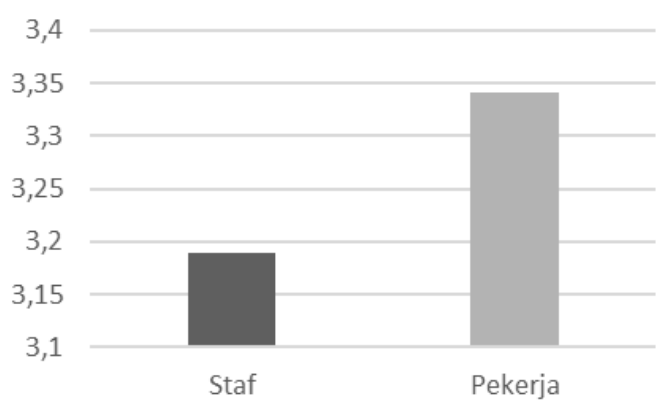

Gambar 8. Nilai Training All Levels Pekerja dan Staf

Nilai Variabel Owner Involvement
Pekerja dan Staf

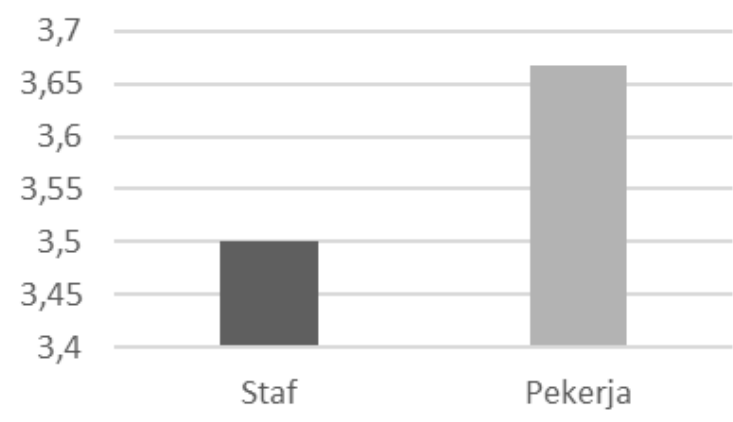

Gambar 9. Nilai Owner Involvement Pekerja dan Staf

Hasil pengambilan kuesioner terkait owner involvement dapat dilihat pada gambar 8 yang menunjukan bahwa nilai owner involvement pekerja ada pada angka 3,67 dan staf memiliki nilai 3,5 dari skala 5

\section{PEMBAHASAN}

\section{Analisis Total Nilai Safety Climate} Proyek

Proyek Z memiliki skor iklim keselamatan 3,79 yang masuk ke dalam kategori proactive. Secara umum angka 
tersebut dapat dikatakan baik dalam organisasi konstruksi, dikarenakan dinamisnya pekerjaan dan tingginya angka turnover di proyek konstruksi (Zou, 2010). Adapun hal yang mempengaruhi angka tersebut adalah tingginya variabel commitment, accountability dan leadership yang mendiskripsikan bahwa variabelvaribel abstrak telah terlaksana dengan lebih baik dibandingkan variabel teknis yang konkret seperti pelatihan dan pemberdayaaan pekerja. Hal ini menandakan bahwa dalam implementasi lapangan pihak Proyek $\mathrm{Z}$ melakukan pendekatan turun langsung / pengarahan di tempat dibandingkan membuat perencanaan dan persiapan untuk menignkatkan performa keselamatan pekerja (Conchie, 2008).

\section{Analisis Variabel Commitment Pekerja dan Staf}

Komitmen Manajemen terhadap keselamatan adalah salah satu faktor terpenting dalam menerapkan perilaku keselamatan yang sukses. Neal dan Griffin mendefinisikan Manajemen Komitmen sebagai 'sejauh mana manajemen dianggap menempatkan prioritas tinggi pada keselamatan dan berkomunikasi dan bertindak atas masalah keselamatan secara efektif' (Neal dan Griffin, 2004). Manajemen bertanggung jawab untuk menetapkan prioritas perusahaan, peraturan, standar kerja dan dengan demikian menjadikan tindakan mereka sebagai indikator utama safety climate (Schwatka et al, 2016). Sebuah studi yang dilakukan oleh Keffane dan Vinodkumar di berbagai negara Asia dan Barat menunjukkan bahwa komitmen manajemen terhadap keselamatan memprediksi kepatuhan keselamatan karyawan. (Keffane, 2014; Vinodkumar dan Bhasi, 2010).

Komitmen manjemen di industri konstruksi rumit dikarenakan pekerjaan konstruksi biasanya dilakukan di lokasi kerja yang berbeda, jauh dari kantor utama perusahaan (Schwatka et al, 2016).
Untungnya, penilaian pekerja mengenai komitmen manajemen mereka di Proyek $\mathrm{Z}$ cukup tinggi. Meskipun ada sedikit perbedaan antara perspektif pekerja kontraktor utama dan pekerja subkontraktor. Sebagian besar staf kontraktor utama berpikir bahwa mereka telah menunjukkan perilaku keselamatan teladan di luar persyaratan. Sementara itu pekerja sub-kontraktor percaya bahwa ketika manajemen hadir di lokasi kerja, mereka hanya harus mengikuti peraturan yang disyaratkan serta kebijakan dan prosedur keselamatan organisasi dengan tepat. Peran manajer atau supervisor dalam sistem keselamatan sangat penting. Dalam salah satu studi kualitatif, ditemukan bahwa supervisor atau manajer keselamatan memegang posisi paling berpengaruh jika membahas faktor keselamatan (Vinodkumar dan Bhasi, 2010) dan dapat mengembangkan efektivitas program ketika mereka mencontohkan perilaku keselamatan seperti memprioritaskan keselamatan di atas produksi dan mendorong pekerja untuk melapor ketika mereka menemukan tindakan tidak aman. (Gillen et al, 2004).

Program Launching Care yang telah dilaksanakan perusahaan menuntut manajemen puncak untuk terus mengomunikasikan komitmennya kepada para pekerja (staf kontraktor utama atau pekerja) dalam sebuah forum bersama. Program khusus ini dapat sangat mempengaruhi pekerja kontraktor terkait dengan komitmen manajemen mereka.

\section{Analisis Variabel Safety as Value Pekerja dan Staf}

Safety Climate berkaitan dengan persepsi individu tentang prosedur, kebijakan keselamatan, dan perilaku di lingkungan tempat kerja (Bosak et al, 2013). Hal ini tentunya dapat diungkapkan dengan adanya nilai keselamatan dalam suatu perusahaan. Nilai keselamatan sangat terkait dengan budaya organisasi. Agar berhasil membangun tempat kerja yang aman, penting untuk mengintegrasikan 
keselamatan sebagai nilai inti perusahaan. Skor pada variabel khusus ini cukup tinggi karena sebagian besar pekerja berpikir bahwa perusahaan tertarik untuk mengintegrasikan nilai-nilai keselamatan pada setiap peluang yang mungkin dilakukan (misalnya, peningkatan berkelanjutan pada program keselamatan dengan indikator utama, keselamatan sebagai isu reguler di setiap pertemuan). Mungkin ada sedikit perbedaan antara skor pekerja subkontraktor dan kontraktor pada kinerja perusahaan mereka dalam mengintegrasikan nilai-nilai keselamatan. Namun, mereka semua sepakat bahwa meskipun dapat melakukan beberapa perbaikan, perusahaan melakukan pekerjaan yang baik dalam menyelaraskan dan mengintegrasikan keselamatan sebagai nilai dengan terlibat dalam berbagai kegiatan.

Kesimpulannya, nilai keselamatan dapat mempengaruhi cara pandang pekerja terhadap keselamatan (Colley dan Neal, 2013). Dapat disimpulkan bahwa status individu memang memberikan kontribusi kepada perusahaan tentang bagaimana mereka menganggap nilai keselamatan dapat mempengaruhi rutinitas kerja mereka sehari-hari. Untuk menjadikan 'Keselamatan sebagai Nilai' menjadi 'Keselamatan sebagai Prioritas', tentunya nilai organisasi harus memiliki dampak yang lebih strategis daripada prioritas. Implementasinya diharapkan dapat dipertahankan untuk waktu yang lama, karena prioritas dapat dengan mudah berubah, dibandingkan dengan nilai yang lebih stabil dari waktu ke waktu. Stakeholder yang sah untuk memperkuat tindakan yang konsisten dari nilai keselamatan adalah manajer puncak dan supervisor. Penting untuk membedakan nilai yang dipegang, dianut, dan akan dikomunikasikan secara lisan dan tertulis. Jika tidak ada perbedaan, karyawan akan tidak percaya pada nilai-nilai tersebut. Pada akhirnya, karyawan akan merasakan nilai keselamatan dengan cara yang lebih praktis dibandingkan dengan manajer.

\section{Analisis Variabel Accountability Pekerja dan Staf}

Akuntabilitas adalah dampak dari kondisi yang ada dari kinerja keselamatan perusahaan (OSHA, 2020) Tanpa sistem formal tentang akuntabilitas, program keselamatan tidak akan efektif dan kepatuhan terhadap aturan atau untuk mengurangi frekuensi atau besarnya kerugian akan berkurang. Cara untuk mendapatkan harapan kinerja mengenai keselamatan dalam aspek kepatuhan pekerja, adalah dengan memasukkan keselamatan dalam deskripsi kerja.

Pekerja harus dilibatkan dan diberi kesempatan untuk memberikan masukan untuk mengembangkan pengukuran kinerja keselamatan. Hal ini tentunya tidak hanya membantu pekerja untuk memiliki gambaran yang jelas tentang tujuan, tetapi juga membantu mereka dengan harapan dan tujuan keselamatan mereka sendiri. Mengenai akuntabilitas keselamatan pada data, manajemen kontraktor utama memiliki distribusi peran dan tanggung jawab yang tepat untuk setiap tingkat manajemen. Namun, pelaksanaan di lapangan masih kurang, terutama karena tidak semua staf kontraktor utama menjalankan peran dan tanggung jawab tersebut. Selain itu, staf kontraktor utama masih fokus pada indikator lagging daripada leading indikator.

\section{Analisis Variabel Leadership Pekerja dan Staf}

Stogdill (1950) dalam Suwarno (2018) berpendapat bahwa kepemimpinan adalah proses yang mempengaruhi aktivitas tim, mengarah pada penentuan tujuan dan pencapaian tujuan. Kepemimpinan dapat didefinisikan sebagai proses di mana seseorang mempengaruhi sekelompok individu untuk mencapai tujuan bersama. Secara umum, staf dan pekerja kontraktor utama memiliki perspektif yang berbeda mengenai kepemimpinan keselamatan. Kontraktor percaya bahwa mereka telah membangun hubungan yang positif dengan 
pekerja dalam bentuk mendorong, berbagi pengetahuan dan pengalaman masingmasing tentang keselamatan, dan memulai diskusi tentang keselamatan di setiap pertemuan. Di sisi lain, pekerja merasa meskipun staf kontraktor utama sering berbicara tentang kesadaran keselamatan, mereka gagal melakukannya. Dalam lingkungan kerja, memformulasikan budaya keselamatan adalah sebuah kewajiban. Konsep ini tidak sebatas pembahasan saja tetapi perlu diberikan contoh langsung dengan menjadi teladan dan melengkapi indikator kinerja utama metrik keselamatan dengan evaluasi deskripsi pekerjaan semua pekerja.

\section{Analisis Variabel Empowerment Pekerja dan Staf}

Praktik

Terbaik

OSHA

menggambarkan partisipasi pekerja sebagai pekerja-termasuk karyawan kontraktor dan subkontraktor-keterlibatan dalam menetapkan, mengoperasikan, mengevaluasi, dan meningkatkan program keselamatan dan kesehatan kerja (OSHA. 2016). Melibatkan pekerja di setiap langkah program keselamatan dan kesehatan kerja meningkatkan kemampuan manajemen untuk mengidentifikasi bahaya, menciptakan rasa memiliki program di antara pekerja, meningkatkan pemahaman mereka tentang cara kerja program, dan membantu membuat program berkelanjutan dari waktu ke waktu (OSHA, 2016).

Standar yang umum digunakan seperti ISO 45001 juga menekankan pentingnya partisipasi pekerja. Penelitian pada proyek $\mathrm{Z}$ menunjukkan bahwa pekerja kontraktor utama dan pekerja memiliki pandangan yang berbeda tentang partisipasi pekerja dalam memastikan keselamatan di area lapangan proyek. Staf kontraktor utama telah secara aktif memberdayakan pekerja dengan melibatkan mereka dalam berbagai kegiatan seperti identifikasi bahaya dan pemecahan masalah terkait keselamatan. Komite keselamatan aktif memberikan saran dan membuat rekomendasi mengenai masalah keselamatan tersedia, tetapi sayangnya tidak ada sistem formal untuk memastikan masukan pekerja terlihat sampai akhir. Pekerja perlu merasa bahwa masukan mereka diterima, suara mereka akan didengar sehingga dapat menimbulkan kepercayaan yang lebih besar terhadap perusahaan (Cooling R, 2011). Di sisi lain, pekerja biasanya paling tahu tentang potensi bahaya yang terkait dengan pekerjaan mereka, daripada manajemen puncak terutama di lingkungan kerja konstruksi. Keterlibatan pekerja dalam program keselamatan dan kesehatan memastikan informasi berguna yang diketahui pekerja diteruskan ke manajemen dan menghasilkan peningkatan berdasarkan pengetahuan itu (Cooling R, 2011). Oleh karena itu penting untuk memastikan rekomendasi pekerja dilihat sampai selesai untuk mencegah bahaya atau risiko yang hilang selama proses identifikasi bahaya oleh petugas keselamatan yang dapat menyebabkan kecelakaan. Tidak hanya itu, efek motivasi dari keterlibatan pekerja dalam hal peningkatan komitmen dan kepuasan kerja - telah banyak dibahas oleh sosiolog dan ilmuwan perilaku (Cooling R, 2011).

\section{Analisis Variabel Communcation Pekerja dan Staf}

Komunikasi adalah salah satu aspek terpenting untuk memastikan keselamatan di lokasi kerja. Keselamatan ditingkatkan jika pengusaha membentuk mekanisme untuk mengoordinasikan upaya mereka dan berkomunikasi secara efektif untuk memberikan perlindungan yang sama kepada semua pekerja terhadap bahaya. Dalam satu struktur organisasi raksasa, komunikasi yang terbuka dan sering mengenai keselamatan dan kesehatan memegang poin penting seperti: menginformasikan pekerja, terutama pekerja sub-kontraktor tentang bahaya, risiko, dan keselamatan berbasis perilaku, dapatkan saran dari pekerja di semua tingkatan untuk cara meningkatkan keselamatan dan kesehatan, 
memungkinkan manajemen dan pekerja untuk belajar dari kesalahan, insiden, dan pengalaman, komunikasi terbuka meningkatkan kepercayaan antara pekerja dan manajemen dan tidak berkomunikasi secara terbuka menguranginya. (Conchie dan Burns, 2008), serta dapatkan informasi penting tentang pengalaman dan kekhawatiran pekerja, terutama mengenai keselamatan (Cigularov et al, 2010).

Data yang terkumpul menyiratkan bahwa meskipun sebagian besar pekerja percaya bahwa komunikasi keselamatan terjadi di jalan dua arah, informasi keselamatan tidak disampaikan dengan tepat. Sebagian besar pekerja berpikir bahwa staf kontraktor utama mereka hanya membagikan data insiden mereka sesekali, padahal sebenarnya ada sistem untuk menginformasikan hal-hal seperti itu secara teratur (misalnya, HSE Board). Tidak hanya itu, masalah tidak dilacak secara formal atau resolusi dikomunikasikan di seluruh organisasi.

Komunikasi dua arah yang efektif setelah kecelakaan, memungkinkan manajemen dan pekerja untuk belajar dari kesalahan dan kesalahan sebelumnya (Hoffman dan Morgeson, 1999) dan dengan demikian membuat mereka mampu mencegah insiden yang sama terulang di masa depan. Hal ini sesuai dengan Zohar dan Polachek (2014), di mana mereka menggambarkan bagaimana komunikasi dapat membentuk persepsi pekerja tentang perilaku keselamatan apa yang diharapkan dan dihargai.

\section{Analisis Variabel Training All Levels Pekerja dan Staf}

Dalam kondisi kerja yang sebenarnya, lokasi konstruksi memiliki situasi yang sangat dinamis dan pekerja di sana rentan terhadap situasi berisiko tinggi. Dalam banyak kasus, sering ditemukan tingkat kecelakaan dan tingkat keparahan yang tinggi. Pelatihan hadir sebagai salah satu program strategis manajemen $\mathrm{K} 3$ dengan tujuan untuk mengubah perilaku tidak aman dan untuk mempromosikan keselamatan
(Bena, 2017). Pelatihan merupakan aspek penting dalam rangka meningkatkan baik soft skill maupun hard skill. Pelatihan mencakup staf kontraktor dan pekerja, hal ini karena staf non-kontraktor juga dapat menunjukkan perilaku keselamatan yang tepat kepada pekerja lain (CITB, 2014). Pelatihan memiliki peran yang sangat signifikan terhadap kinerja, yaitu (1) Pelatihan berpotensi untuk meningkatkan produktivitas tenaga kerja, (2) meningkatkan kualitas output, (3) dan meningkatkan kemampuan pekerja dan staf (karyawan) untuk beradaptasi di lingkungan kerja. setiap situasi dinamis (Smith et al, 1997). Namun, akumulasi data dalam proyek $\mathrm{Z}$ menyiratkan bahwa baik pekerja atau staf kontraktor utama merasa bahwa mereka tidak mendapatkan pelatihan yang cukup dan layak.

Menurut pekerja, manajemen puncak memberikan pelatihan keselamatan hanya dalam bentuk pelatihan informal yang biasanya diadakan pada pertemuan kotak peralatan. Sebaliknya, pelatihan bersertifikat (misalnya, tukang las, perancah, dan sebagainya) langka. Apalagi dari segi kuantitas, pekerja menerima lebih banyak pelatihan daripada staf karena manajemen puncak menganggap pekerjalah yang langsung bekerja di gedung; Sementara itu, sebagian besar staf kontraktor utama menangani pekerjaan yang bersifat manajerial.

\section{Analisis Variabel Owner Involvement Pekerja dan Staf \\ Owner atau sering disebut dengan} Klien, adalah pemilik yang membayar kontraktor untuk menjalankan suatu proyek. Pada umumnya kontraktor adalah pihak yang menyesuaikan aspek keselamatan dengan preferensi pemilik. Jika pemilik kurang memperhatikan aspek keselamatan, maka akan tergambar dalam kinerja keselamatan staf konstruksi. Hal ini dapat terjadi karena keterlibatan pemilik dapat mempengaruhi kepemimpinan, budaya dan perilaku kontraktor terhadap aspek keselamatan (Zou, 2010), bahkan 
pada proses pembangunan. Dalam variabel ini, keterlibatan pemilik dari perspektif staf kontraktor utama hanya sebatas kepatuhan saja.

Keterlibatan pemilik juga terlihat pada pekerjaan awal. Selain itu, Pencegahan melalui Desain juga dapat dimanfaatkan oleh pemilik untuk memastikan keamanan dalam semua desain proyek mereka. Dalam konteks ini, desain adalah cara untuk menghemat pengeluaran untuk mencegah terjadinya kecelakaan dengan menghemat sejumlah dana untuk proyek-proyek tersebut (CITB,2014). Selain itu, untuk menilai komitmen pemilik terhadap keselamatan dapat disimpulkan dari program asuransi yang dikendalikan. Pemilik dapat memberikan asuransi kompensasi bagi pekerja untuk memastikan tempat kerja yang aman (AIHA, 2017). Dalam praktiknya, pemilik setuju bahwa keselamatan itu penting; namun, menurut mereka, produktivitas jauh lebih penting daripada keselamatan. Pada tahap perencanaan, pemilik hanya memasukkan aspek keselamatan jika ada masukan dari ahli K3 atau kontraktor, sedangkan pemilik tidak memiliki inisiatif lebih perihal K3.

\section{KESIMPULAN}

Dari penelitian kami, kami dapat menyimpulkan bahwa tingkat kematangan iklim keselamatan proyek $\mathrm{Z}$ berada pada tingkat proaktif (3,79 hingga 4$)$. Hal ini menandakan bahwa dalam implementasi lapangan pihak Proyek $\mathrm{Z}$ melakukan pendekatan turun langsung / pengarahan di tempat dibandingkan membuat perencanaan dan persiapan untuk menignkatkan performa keselamatan pekerja. Oleh karena itu, variabel abstrak seperti komitmen, akuntabilitas dan melihat keselamatan sebagai nilai adalah poin dengan nilai tertinggi.

Beberapa variabel yang masih kurang, peneliti berikan berbagai referensi prioritas pengembangan sebagai berikut

Variabel keselamatan sebagai nilai, disarankan untuk membuat pernyataan tertulis yang menyatakan keselamatan sebagai nilai prioritas organisasi dan berkomunikasi dengan semua karyawan (kontraktor dan subkon). Pada variabel Kepemimpinan Akuntabilitas dan Keselamatan peneliti menyarankan untuk semua indeks kinerja utama departemen harus mencakup evaluasi keselamatan berdasarkan deskripsi pekerjaan masingmasing.serta Staf kontraktor utama harus menjadi panutan bagi pekerja dalam hal perilaku keselamatan.

Pemberdayaan bagi pekerja harus didukung melalui sistem pemantauan yang mencakup masukan keselamatan setiap pekerja dianalisis oleh komite keselamatan dan dapat dilihat oleh semua orang di lokasi kerja. Adapula Penghargaan bagi pekerja yang sering memberikan masukan berkualitas terkait keselamatan harus terus diperhatikan

Aspek Komunikasi dalam tren keselamatan adalah topik wajib dalam setiap pembicaraan keselamatan. Manajemen harus mau terbuka untuk meminta pekerja untuk memberikan solusi terkait masalah keselamatan (penerapan konsultasi dan komunikasi)

Untuk mengembangkan pelatihan di Semua Tingkat. Tim harus konsisten untuk membuat matriks analisis kebutuhan pelatihan untuk pekerja dan staf. Serta memprioritaskan untuk mendakaan pelatihan bersertifikat dan refreshment secara berkala kepada pekerja dan staf.

\section{UCAPAN TERIMA KASIH}

Peneliti mengucapkan terima kasih kepada rekan-rekan Proyek X PT. Z dan teman-teman yang telah membantu berjalannya proses pengambilan data serta penyusunan penelitian ini.

\section{DAFTAR PUSTAKA}

AIHA - American Industrial Hygiene Association. (2017). How to Improve the Safety Climate on Your Construction Site. p.31-32,. 
Bena, A., Berchialla, P., Coffano, M. E., Debernardi, M. L., \& Icardi, L. G. (2009). Effectiveness of the training program for workers at construction sites of the highspeed railway line between Torino and Novara: impact on injury rates. American journal of industrial medicine, 52(12), 965972. https://doi.org/10.1002/ajim.20770

Bosak, J., Coetsee, W., Cullinane. (2013). Safety climate dimensions as predictors for risk behavior. In Journal Science Direct : Accident analysis and prevention. 55C. 256264. 10.1016/j.aap.2013.02.022.

Chung, J. K. H., \& Chung, J. (n.d.). Owners Responsibilities in Construction Projects Singapore Experience Intelligent Solutions for Dependable Built Environment View project Frontiers in Construction Management View project Owner's Responsibilities in Construction Projects: Singapore Experience. https://www.researchgate.net/publication/2 85512153

Cigularov, K. P., Chen, P. Y., \& Rosecrance, J. (2010). The effects of error management climate and safety communication on safety: a multi-level study. Accident; analysis and prevention, 42(5), 1498-1506. https://doi.org/10.1016/j.aap.2010.01.003

CITB - Construction Industry Training Board. (2014). Skills and Training in the Construction. p.25-28.

Colley, S., Lincolne, J., \& Neal, A. (2013). An examination of the relationship amongst profiles of perceived organizational values, safety climate and safety outcomes. Safety Science, 51, 69-76.

Conchie, S. M., \& Burns, C. (2008). Trust and risk communication in high-risk organizations: a test of principles from social risk research. Risk analysis : an official publication of the Society for Risk Analysis, 28(1), 141-149. https://doi.org/10.1111/j.15396924.2008.01006.X

Cooling, R. F. (2011). The law and management of worker involvement in safety and health.: Retrieved from https://search.proquest.com/dissertationstheses/law-management-workerinvolvement-safetyhealth/docview/1687704834/se2 ? accountid $=17242$
Gillen, M., Kools, S., Sum, J., McCall, C., \& Moulden, K. (2004). Construction workers' perceptions of management safety practices: a qualitative investigation. Work (Reading, Mass.), 23(3), 245-256.

Hofmann, D. A., \& Morgeson, F. P. (1999). Safety-related behavior as a social exchange: The role of perceived organizational support and leader-member exchange. Journal of Applied Psychology, 84(2), 286296. https://doi.org/10.1037/0021 9010.84.2.286

Jazayeri, E., Liu, H., \& Dadi, G. B. (2017). Perception Differences between Contractors and Owners Regarding Drivers of Construction Safety Health Monitoring of Bridges and Structures View project STRUCTURAL HEALTH MONITORING View project Perception Differences between Contractors and Owners Regarding Drivers of Construction Safety. Journal of Safety Engineering, 2017(2), 29-39. https://doi.org/10.5923/j.safety.20170602.0 2

Keffane, S. (2014). Communication's Role in Safety Management and Performance for the Road Safety Practices. International journal of transportation science and technology, 3, 79-94.

Neal, A., \& Griffin, M. A. (2004). Safety climate and safety at work. In J. Barling \& M. R. Frone (Eds.), The psychology of workplace safety (pp. 15-34). American Psychological

Association. https://doi.org/10.1037/10662002

OSHA. (2016) Recommended Practices for Safety and Health Programs in Construction.

OSHAcademy. (2020). Course 116 : Introduction to Safety Accountability. Geigle Safety Group, Inc,.United States:

Probst, T., Goldenhar, L., Byrd, J., Betit, E. (2019). The Safety Climate Assessment Tool (S-CAT): A rubric-based approach to measuring construction Safety climate. Journal of Safety Research. 69. 10.1016/j.jsr.2019.02.004.

Schwatka, N. V., \& Rosecrance, J. C. (2016). Safety climate and safety behaviors in the construction industry: The importance 
of co-workers commitment to safety. Work (Reading, Mass.), 54(2), 401-413. https://doi.org/10.3233/WOR-162341

Smith, E. M., Ford, J. K., \& Kozlowski, S. W. J. (1997). Building adaptive expertise: Implications for training design strategies. In M. A. Quiñones \& A. Ehrenstein (Eds.), Training for a rapidly changing workplace: Applications of psychological research (pp. 89-118). American Psychological

Association. https://doi.org/10.1037/10260004

Soemardi, B.W., Fajri, A., and Wulan, S. (2009). Study on the Effectiveness of Construction Safety Regulation in Indonesia. In First Asean Civil Engineering Conference, Pattaya, Thailand, 12-13 March.

Vinodkumar, M. N., \& Bhasi, M. (2010). Safety management practices and safety behaviour: assessing the mediating role of safety knowledge and motivation. Accident; analysis and prevention, 42(6), 2082-2093. https://doi.org/10.1016/j.aap.2010.06.021

Zou, P. X. W., Chen, Y., \& Tsz-Ying, C. (2010). Underst and improving your RM capability: Assessment Model for Construction Organizations Zou et al 2010.pdf. Journal of Construction Engineering and Management, 136(August), 854-863. 